\title{
State-society relations and the sources of support for the Putin regime: bridging political culture and social contract theory
}

\section{Magnus Feldmann \& Honorata Mazepus}

To cite this article: Magnus Feldmann \& Honorata Mazepus (2018) State-society relations and the sources of support for the Putin regime: bridging political culture and social contract theory, East European Politics, 34:1, 57-76, DOI: 10.1080/21599165.2017.1414697

To link to this article: https://doi.org/10.1080/21599165.2017.1414697

Published online: 13 Dec 2017.

Submit your article to this journal $\sqsubset$

Џلll Article views: 689

View Crossmark data $\subset$ 


\title{
State-society relations and the sources of support for the Putin regime: bridging political culture and social contract theory
}

\author{
Magnus Feldmann ${ }^{\mathrm{a}}$ and Honorata Mazepus ${ }^{\mathrm{b}}$ \\ ${ }^{a}$ School of Sociology, Politics and International Studies, University of Bristol, Bristol, UK; ${ }^{b}$ Institute of Security \\ and Global Affairs, Leiden University, Leiden, Netherlands
}

\begin{abstract}
This article evaluates two theoretical approaches to the popularity and resilience of authoritarianism in Russia, namely political culture and social contract theory. These approaches are two of the most important theories of Russian politics and also reflect the general divide in comparative and post-communist politics between political-cultural and rationalist explanations. We demonstrate that these approaches are bound up with different notions of legitimacy. This article suggests that neither framework offers a complete explanation of the Russian case. We develop an alternative framework that bridges these two approaches. Our analysis suggests that the social contract in Russia needs to be analysed as dynamic and conditional. Moreover, the use of different legitimation strategies by Russian authorities suggests that leaders can reshape the social contract and gain support in a strategic fashion by choosing appeals related to political culture.
\end{abstract}

\section{ARTICLE HISTORY}

Received 27 August 2016

Accepted 13 November 2017

KEYWORDS

Russia; regime stability; legitimacy; social contract; political culture; Putin

\section{Introduction}

What accounts for the stability and popularity of the Putin regime in Russia? Given the authoritarian turn during the Putin era, this question has already attracted attention in popular as well as scholarly debates in Russia and in the West. As scholars stressing the strength of the Middle Eastern regimes prior to the Arab Spring or of the communist countries in the early 1980s have realised, it is easy to overstate authoritarian stability and popularity, not least given electoral manipulation as well as restrictions on the media (Schedler 2002). While this makes it difficult to assess just how great the support for the Putin regime is - and how easily it might unravel in the face of freer media and honest and competitive election campaigns - there is considerable evidence to suggest high support for the government and the president in particular (Frye et al. 2016).

Given the robust democratic awakening in the late 1980s and early 1990s, many observers predicted that Russia would develop into a Western-style democracy. Therefore, the popularity of the authoritarian turn under Putin is puzzling. It seems clear that Russia's political system offers limited scope for popular input, as elections are not free and fair and competition in the political realm is limited. This has even led some analysts to speak of a "Sovietization of Russian politics" (Kryshtanovskaya and White 2009). 
This article evaluates two theoretical approaches to the resilience of authoritarianism in Russia, namely political culture and social contract theory. These are two of the most influential approaches to Russian politics and reflect the divide in comparative and post-communist politics between political-cultural and rationalist explanations (Eckstein 1988; Whitefield and Evans 1999). As both theories are quite abstract and hard to test, we seek to operationalise them by demonstrating how they are bound up with different notions of legitimacy (for a summary, see Table 1). This is an important concept for understanding political stability in Russia (Sil and Chen 2004). The starting point of the concept of legitimacy is the justification of power through the pursuit of the common good of society. This distinguishes the legitimate exercise of power from merely effective exercise of power. In other words, legitimacy is a form of generalised support and trust in existing political institutions that does not exclusively depend on personal advantage or securing specific gains. It is based on values that benefit the community as a whole both in a material and ethical sense.

The political culture approach is bound up with traditional and charismatic forms of authority and legitimacy that are often seen to be rooted in Russian history and culture (Pipes 2004; Hedlund 2005). This approach implies that Russian support for authoritarianism might be quite stable and even unconditional, as the prevailing political culture predisposes people towards favouring strong authoritarian leadership and against democratic governance. From this perspective, neither the democratic reversal nor the popularity of authoritarianism is surprising.

The second approach, based on social contract theory, has been advanced by some Russian scholars (Auzan 2009; Makarkin and Oppenheimer 2011) and implies that Russians are less uncritical in their assessment of Putin's rule than some Western observers suggest. Russian support for the Putin regime amounts to a form of "conditional tolerance" (Pakulski 1986) - i.e. Russians are willing to give up free elections (and renounce on demands for "input legitimacy") if the regime delivers its part of the bargain in terms of good economic outcomes (i.e. "output legitimacy" is satisfied).

This article suggests that both explanations are incomplete. The first explanation, emphasising political culture, overstates the depth of support for the Putin regime. ${ }^{1}$ Given that cultural factors are relatively durable and change only slowly, this explanation struggles to address why support for democracy has varied over time - notably, why it was quite high in the early 1990s and why there have been some fluctuations in the support for key democratic processes, such as the direct election of governors (Makarkin and Oppenheimer 2011, 1468). In other words, this would confirm that Russians are not inherently undemocratic, as also shown by Colton and McFaul (2002). While there is some evidence in support of the social contract explanation, i.e. the idea that the support for the

Table 1. Comparing the two theoretical approaches.

\begin{tabular}{lll}
\hline & \multicolumn{1}{c}{ Political culture } & \multicolumn{1}{c}{ Social contract } \\
\hline $\begin{array}{l}\text { Primary basis for } \\
\text { legitimacy }\end{array}$ & Traditional and charismatic legitimacy & Output legitimacy (or performance legitimacy) \\
implications & $\begin{array}{l}\text { High level of unconditional support for strong } \\
\text { presidency and low demand for political } \\
\text { participation }\end{array}$ & $\begin{array}{l}\text { Conditional tolerance: high perceived output } \\
\text { legitimacy reduces demand for political } \\
\text { participation and compensates for low input } \\
\text { legitimacy }\end{array}$ \\
\hline
\end{tabular}


authoritarian turn is contextual (initially prompted by the perception of chaos in the 1990s) and fuelled by the perception of good regime performance in terms of economic growth, it is relatively hard to distinguish between the political culture and social contract approaches in the period 1999-2007. Both approaches predict high support for the regime at that time, but the predictions of the two approaches diverge during the economic crisis. We show that the social contract approach cannot fully explain the support for the political regime during the global economic crisis when economic performance deteriorated.

We develop an alternative framework that bridges these approaches and extends them in important ways. First, as both research on the Soviet Union and on contemporary Russia has shown that the stability of social contracts cannot be taken for granted, we suggest that social contracts must be understood in dynamic terms and that we need to focus on the ways in which social contracts are maintained and renegotiated over time. Second, we integrate insights from scholarship on political culture to suggest that culture should not be understood as a rigid structural constraint, but that it can also serve as a resource which political leaders can draw on for political legitimation strategies. As Swidler (1986) has shown, culture can be understood as a toolkit or repertoire of symbols, stories and worldviews that actors can use to construct strategies of action. We argue that support for the Putin regime can be understood as a social contract, but that the regime has been able to redefine the terms of the contract, notably during the economic crisis, when oil prices and economic growth have fallen. By raising the salience of national security and nationalism as key performance indicators, assessments of the regime in terms of performance have remained favourable. The significance of these appeals resonates with a political-cultural approach.

The article is structured in the following way. The next section outlines the approaches to authoritarian stability in Russia based on political culture and social contract theory. It shows how these approaches imply different forms of political legitimacy, and it discusses the alternative framework proposed in this article, which builds on these approaches. The following sections evaluate these approaches by examining empirical data. As we were not able to run our own survey to test these hypotheses, we use descriptive statistics from survey data to illustrate relevant developments in state-society relations in Russia. The final section concludes with some general lessons from this analysis about the stability of the Putin regime and authoritarian resilience more generally.

\section{Political culture and social contract theory}

Political culture has long been an important approach to political science and political sociology, though its influence on academic debates has fluctuated. Sidney Verba, an influential contributor to the literature on political culture, has stated that "The political culture of a society consists of the system of empirical beliefs, expressive symbols and values which defines the situation in which political action takes place. It provides the subjective orientation to politics." (Verba 1965, 513). Lucian Pye's definition of political culture "encompasses both the political ideals and the operating norms of a polity .... [It] is thus the manifestation in aggregate form of the psychological and subjective dimensions of politics" (Pye 1968, 218). There are different ways of studying political culture (Wilson 
2000), but all of them analyse the ways in which beliefs and understandings of politics vary across countries and shape political systems and behaviour.

The concept of political culture has been influential in scholarship on Russia (Brown 1985; Whitefield 2005). For example, Richard Pipes develops an argument about Russian political culture and attitudes towards democracy premised on the idea that "Russia is a remarkably conservative nation whose mentality and behavior change slowly, if at all, over time, regardless of the regime in power" (Pipes 2004, 9). Many scholars who adopt a political culture approach to Russian politics stress the country's distinctive historical traditions and political history, including norms related to the mir system, the philosophical concept of sobornost' (Biryukov and Sergeyev 1993) and étatisme (Tucker 1992), all of which creates a strong sense of path dependence in values and political developments (Hedlund 2005). Many studies of Soviet politics have also highlighted "Soviet patriotism" and a general political culture in which restrictions on free speech and protest are viewed as normal (e.g. Connor 1988, 70-75).

Traditional norms may predispose Russians against dissent and towards maintaining a community-based or national consensus on key issues. Analysts working within this approach see the tradition of a strong state and central leadership, exercised by a Czar or President - as deeply entrenched in Russian political culture. A variety of historical, geographical, military, economic, and other reasons are seen to have contributed to shaping a political culture that attaches little value to democracy and favours strong authoritarian and centralised rule.

In relation to the traditional Weberian classification of political legitimacy, this kind of regime support is closely related to traditional legitimacy and charismatic legitimacy, at least to the extent that this is personified in support for an individual leader. In this sense, political legitimacy in authoritarian regimes differs radically from modern legalrational legitimacy (cf. Jowitt 1983).

Some Western scholars have been sceptical of applying this approach to the study of Russia (Colton and McFaul 2002), not least since cultural explanations are often quite deterministic and poorly equipped to explain processes of change (Hall 1986, 8-9; Holmes 2015). However, it should be noted that the political culture approach remains influential in Russia (e.g. Biryukov and Sergeyev 1993).

If the traditional political culture approach provides an accurate account of Russian politics, there should be several observable implications, notably high support for authoritarian institutions and low support for democracy. Levels of support should not vary greatly over time, as culturally determined preferences and norms are relatively stable.

The second approach considered in this article relates to a variety of social contract theory that has played an important role in empirical scholarship on the Soviet Union and contemporary Russia. This should be distinguished from definitions of the social contract in much of democratic theory and Western political thought that stress popular approval and inputs. ${ }^{2}$ By contrast, the communist social contract was generally dictated by the state (Cook and Dimitrov 2017, 8). Social contract theory became influential in the last decades of communist rule when the totalitarian model no longer seemed appropriate. On the one hand, the totalitarian model seemed to overstate the intensity of state and party control, which in the post-Stalinist period was perceived as less pervasive than before. On the other hand, it overstated the passivity, fear and manipulation of the population, not just in the case of dissidents, but also in the population at large, where cynicism, 
questioning and different forms of active and passive resistance were possible. As this suggested that significant parts of the Russian population tolerated and even accepted at least some aspects of communist rule and that this was not just induced by fear, the social contract approach was proposed as an alternative framework for understanding communist rule. For example, Linda Cook's influential work identified a "tacit social contract" between the Soviet regime under Brezhnev and its working class:

According to the terms of the contract, the regime provided full and secure employment, egalitarian wage policies and lax performance pressures in industry, state-controlled and heavily subsidised retail prices for essential goods and socialised human services. (i.e. education, medical care, child care, etc.) (Cook 1992, 37)

Cook suggests that this contract acted as a severe constraint on the regime, which had to deliver key outcomes or "lose legitimacy among workers and risk open discontent". Stephen White also identifies economic performance as the most important legitimation strategy of communist regimes and suggests that the trade-off between economic welfare and lack of participation can be interpreted as a form of social contract (White 1986, 463).

Hauslohner (1987) offers a more complex definition of the social contract as a set of norms, or "implicit conventions which have been widely accepted by the public and the elite as expected and fair rules of the economic game". Like Cook (1992), Hauslohner $(1987,59-60)$ identifies blue collar workers as the main beneficiaries of the Soviet social contract, and he stresses the importance of institutionalisation, notably the centrality of institutions like the Labour Ministry, which implemented and defended associated policies over time.

More recently, scholars have explored the notion of a social contract in post-communist Russia (Greene 2012; Cook and Dimitrov 2017). For example, Wegren (2003) has examined the transformation of the social contract in rural Russia, and Holmes (2001) has suggested that there was a social contract between the political and economic elites in the 1990s that was detrimental to society at large. Cook and Dimitrov (2017) show that social welfare provision plays a more limited role in the social contract of post-communist Russia than in the Soviet Union. Others have analysed the applicability of social contract thinking to Soviet and post-Soviet workers (Ashwin 1998). There is also an alternative approach to social contract theory in Russia based on input legitimacy. Such studies generally conclude that there has never been a social contract between Russian rulers and society (e.g. Alexei Levinson in Chechel' and Markov 2015).

There has also been considerable interest in the social contract in Russia in recent years. Dmitry Medvedev referred to the importance of having a social contract in some of his speeches as prime minister of Russia (Sakwa 2008, 894). In 2000, the independent nongovernmental organisation (NGO) National Project Institute "Social Contract" was established. It is directed by Economics Professor Alexander Auzan, and this organisation has actively contributed to debates and sponsored publications about the social contract and its importance to Russia. Auzan (2009) views the social contract as increasingly important and even indispensable in contemporary Russia.

Similarly, Makarkin defines a social contract as a bargain, where the population accepts the regime, provided the state is able to "guarantee a reasonable quality of life for the majority of the population". Makarkin and Oppenheimer $(2011,1467)$ suggests that such a contract existed for much of the Soviet period, when the bargain entailed stability 
in exchange for loyalty. Auzan $(2009,24)$ states that the social contract "is an exchange of expectations concerning rights and freedoms and it is rarely formally expressed. A social contract regulates informal rules at a very high level." ${ }^{3}$ The Russian scholars' analysis suggests that one of the main problems of Russia in the 1990s was the lack of a social contract or any broad-based agreement (e.g. Bogayevskaya et al. 2001). Given the unstable economic situation and the first war in Chechnya, people remained highly politicised and distrustful of the authorities, hence welcoming direct elections of governors and single-member constituencies as a way of manifesting discontent with the authorities (Makarkin and Oppenheimer 2011).

Makarkin suggests that the social contract was re-established under Putin when people saw that wages and pensions were being paid on a more regular basis and the state as capable of restoring "order". According to Auzan (2009), Russian citizens agreed to a deal with the authorities in which they exchange "stability [in the country] for political freedoms". The shock of the economic transition in the 1990s that left most Russians in a tragic economic situation and the "low demand for democracy" from citizens (Auzan 2009) contributed to the new arrangement of state-society relations after the collapse of the Soviet Union. Economic performance became the sole basis for citizens' evaluations of the authorities due to the hardship caused by the abrupt transition from a centrally planned economy to a market-based system, and by the continuing shortcomings in establishing democratic mechanisms and institutions strengthening social control over the political system. In summary, Russian scholars view the social contract - a set of informal rules and an exchange of expectations as part of an implicit bargain between society and the authorities - as an essential basis for legitimacy and effective modernisation of the country. Its importance is underscored by concerns that there may be instability if the authorities are unable to renew the social contract under changing circumstances (Auzan 2009).

Table 1 summarises the two approaches. It should be noted that they have profound and divergent implications for our understanding of authoritarian stability in Russia. If the political culture approach is correct, we should expect authoritarianism to be quite stable, as authoritarian institutions resonate with popular understandings of politics. On the other hand, if the social contract view is accurate, then stability is less certain and conditional on the authorities delivering their part of the bargain.

We show that neither of these perspectives can provide a complete account of the high support for the Putin regime. Therefore, this article also develops a third approach, which draws on elements of both theories but extends them in important ways. First, this approach conceptualises the social contract in dynamic terms. As noted by Auzan (2009) and Makarkin and Oppenheimer (2011), the stability of social contracts cannot be taken for granted. Rather than viewing it as a stable bargain ensuring both conditional tolerance and regime legitimacy, we need to focus on the ways in which social contracts are maintained and renegotiated over time and the legitimation strategies the regime uses to accomplish this. If the terms of the agreement change over time, then the importance of specific performance indicators to assessing output legitimacy can also change. Secondly, we draw on a more nuanced account of political culture, which is not merely understood as a structural constraint, but also as a resource which political leaders can draw on for political legitimation strategies. Political leaders have various tools at their disposal, including strategic agenda-setting, framing of policy issues as well as attempts to 
increase the salience of some issues at the expense of others. This relates to Riker's concept of "heresthetics" as the dynamic manipulation of conditions of choice (Riker 1984). This may include a variety of administrative resources, which are likely to be particularly important in authoritarian and hybrid regimes. In addition, the degree to which such a legitimation strategy resonates with the public and becomes embedded in a social contract or a set of norms specifying popular and elite expectations from the regime, may be related to political culture. In the empirical part of this article, we argue that the Putin regime has been able to redefine the terms of the Russian contract during the economic crisis, by raising the salience of national security and nationalism as key performance indicators during the period when oil prices and economic growth fell. This has ensured that assessments of the regime remained favourable despite deteriorating economic performance, which had been a central plank of the social contract under Putin before 2008 (Auzan 2009).

\section{Empirical assessment}

\section{Political culture: traditionalism and charismatic leadership}

Scholars, such as Pipes (2004), have argued that Russians have a strong cultural preference for authoritarian rule and that they do not value democracy, which is viewed as a weak political system. Other scholars have found that regime support in Russia is based on paternalistic ideas, which prevail not only among the rulers but among Russians in general. Gudkov et al. $(2001,18)$ found that Russians tend to hold traditional views about the ruler as a father-figure, who "needs to support order in society and secure known minimum of consumer goods and social guarantees". Citizens do not believe they have an active role. Key reasons for this include the rulers' unwillingness to cede control over society and the inability to imagine alternative arrangements (Gudkov et al. 2001). A possible source of legitimacy in such a regime is ideology, which could reflect deeply held values about the nature of the state, social justice and their place in the system or guide people towards a vision of the future, as in the case of the Communist Party in the Soviet Union (Di Palma 1991). However, contemporary Russian elites do not have a coherent ideology of the communist kind that could serve as a source of legitimacy.

Although Putin is not necessarily inherently charismatic, he enjoys significant charismatic authority that contributes to support for the presidency and the regime (Sakwa 2008, 882; White and McAllister 2008). This helps account for the president's high approval ratings, although the system overall is not perceived as working for the general good of citizens. Between 2007 and 2013, more than 50\% of respondents surveyed by Levada Center (2013) consistently stated that the interests of government and society did not correspond with each other. In 2013,67\% of respondents said that the government did not act in the interests of citizens. Even Putin, the most popular politician in Russia with approval ratings over $60 \%$ at the time, was believed primarily to represent the interests of siloviki (46\%), oligarchs (38\%), and the state bureaucracy $(33 \%)$, rather than society at large (14\%) (Levada Center 2014c).

Yet there are several reasons why such approval ratings cannot be fully explained by unconditional support for Putin (charismatic legitimacy) or by some culturally rooted preference for authoritarianism (traditional legitimacy). First, there are examples of high 
profile protests which illustrate that tolerance is not unconditional. This includes the election protests in 2011-2012, the protests to save the Khimki forest in 2010, and the pensioners' protests against the monetisation law in January 2005, which replaced free services (such as public transport) with cash payments (Robertson 2011, 176). New consolidated data on protest activity in Russia (Lankina 2015) show that political protests were the most common form of protest in 2007-2012. Civic protests (about legal, cultural, and environmental issues) are the second most frequent type of protests in this period (Lankina 2015, 38). Second, the approval ratings of President/Prime Minister Putin fluctuate, ranging between 61\% in November 2013 and 89\% in June 2015 (Levada Center 2015a). This indicates that people are not entirely uncritical of Putin's rule and that their assessments change considerably over relatively short periods of time. Third, there does not seem to be consistent support for authoritarianism among Russians. Numerous studies have demonstrated that many Russians do support democratic rules (Colton and McFaul 2002; Hahn 2005; Carnaghan 2007; Mickiewicz 2014).

Finally, if support for Putin were unconditional, then it is unclear why Putin's regime would seek to undermine fair elections and deny opposition candidates full access to the public sphere (White 2011). This suggests that support for Putin is not necessarily deep or unconditional. Some polls indicate that people may support Putin because they do not see any viable alternatives (Holmes 2015, 51).

\section{Social contract}

It seems clear that Russia does not have a social contract based primarily on input legitimacy, as there are limited opportunities for citizens to hold rulers accountable. (e.g. Alexei Levinson in Gudkov et al. 2001; Chechel' and Markov 2015). Most responses to questions in the Levada Center and European Social Survey indicate that input legitimacy is low. While elections are the main source of input legitimacy in democracies, only $5 \%$ of Russians are sure that elections in their country are free and fair and additional $29 \%$ are fairly convinced, according to data from the 2012 European Social Survey wave. On the other hand, $12 \%$ do not believe that there are free and fair national elections, while another $29 \%$ are rather sceptical. The Levada Center polls before the 2016 parliamentary elections showed that a rather low number of respondents were convinced that the elections would be conducted without any abuses (20\%), with the rest either having difficulty answering this question (26\%) or naming different types of electoral abuses (Levada Center 2016). The same poll in May 2016 showed that 44\% of respondents believed that the elections would be fair, whereas $38 \%$ believed they would be "dirty" involving the use of different types of manipulations. The results were further nuanced by Volkov (2016), who showed that the satisfaction with fairness of elections is very high mostly among United Russia voters.

As noted above, this article defines the social contract by drawing on Pakulski's concept of conditional tolerance. This implies that support for the leadership and for Putin's rule is shaped by current perceptions of performance in terms of generating key outputs. As Auzan (2009) and Feklyunina and White (2011) have noted, economic performance in the form of high economic growth and rising living standards has arguably been the key output underpinning regime legitimacy. This implies that citizens' attitudes towards the Putin regime are positive or at least neutral if the authorities can secure a sense of 
economic stability (Colton and Hale 2009; Treisman 2011). More generally, high levels of support correlate with economic performance: this pattern was observed in the Soviet Union under Brezhnev, whose regime delivered stable prices and wages for the working class, but also under Putin, who is credited with the economic growth in the 2000s (Gudkov et al. 2001, 44; Treisman 2011).

There is some empirical evidence of a social contract based on conditional tolerance. For example, a large section of the Russian population is willing to give up some of their freedoms if they can expect a "normal salary and reasonable pension" from the state. Between 2002 and 2015 around 40\% of Levada Center respondents consistently declared that they would agree or rather agree to trade their freedom of speech and freedom to travel for these provisions (Levada Center 2015d). This is reminiscent of what Rigby and Fehér (1982, 64-81) describe as paternalistic legitimation of communist rule in the post-Stalinist era. In this model, citizens traded their individual freedoms for secure jobs without competition as well as access to health-care and schooling. These figures are also an indication of the priority assigned to material well-being by a substantial part of Russian society. Moreover, in their analysis of longitudinal survey data from New Russia Barometer between 1992 and 2009, Rose, Mishler, and Munro (2011, 101) found that satisfaction with the current national economy had the largest and most consistent effect on regime support in Russia. Presidential approval had the second largest significant effect, but it depended on the evaluation of the economic situation too. According to Volkov (2014), economic conditions underpin Putin's support and the stability of the political system. He emphasises that declines in Putin's popularity coincide with economic crises and that sociological observations of Russians since the collapse of the Soviet Union show that the main concerns of the population are of an economic nature.

To the extent that the social contract is based on the idea that the government should deliver outcomes perceived to further the common good, it can be seen as related to output legitimacy. According to Gilley's guidelines, we can talk of legitimacy when a citizen supports the regime "because it is doing well in creating jobs" and not when a citizen simply supports the regimes "because I have a job" (Gilley 2006, 502). If people give priority to economic factors, it is very difficult to discern whether they are concerned with their personal well-being or with the common good. This difficulty holds also in the case of Russia. If regime support is based on an assessment of general performance, we could speak of output legitimacy as understood by Gilley. In practice, it is hard to distinguish this empirically from instrumental motivations or rule out the possibility that citizens are primarily interested in sustaining their personal welfare, but the fact that increasing support for the Russian political regime coincides both with the authoritarian turn and with improvements in most economic indicators during the high growth period (2000-2007) compared to the 1990s is consistent with conditional tolerance.

\section{The global economic crisis}

Russia experienced another economic crisis in 2008 in conjunction with the global financial crisis. Economic crises can challenge a social contract based on the provision of material welfare. An overt form of challenging political authorities is social protest. Levels of protest generally correlate inversely with economic outcomes. This could be observed during the Soviet period, including the perestroika period. 
Therefore, the economic crisis is an important test case for the theoretical approaches discussed in this article. As noted earlier, it is in effect difficult to make a conclusive distinction between them in the period 2000-2007. High levels of support for the Putin regime could be explained both with reference to traditional cultural values (Pipes 2004) and as a result of conditional support based on high rates of economic growth and rising living standards or performance legitimacy (Feklyunina and White 2011). During the economic downturn, the predictions associated with the two theories are very different. If the political culture account is correct, then support for the regime should be unconditional and stable, whereas a social contract view would imply that support is conditional and that it would fall as a result of deteriorating economic performance.

The effect of the global economic crisis of 2008 on the Russian economy has been profound, because of the structure of the Russian economy and high dependence on oil prices (see Table 2; Gaddy and Ickes 2010). In 2014-2015, the Russian economy suffered again due to falling oil prices and financial sanctions imposed on Russia. It is difficult to estimate independent effects of these financial factors, but available evidence suggests that the impact of the sanctions on GDP and the Russian currency was significant, albeit not as great as that of the oil price shock (Dreger et al. 2016). In mid-2014 Russia fell into recession, and this downturn affected citizens too. According to official statistics for the first quarter of 2015, the number of Russians living below the nationally defined poverty line (minimum subsistence) increased by 3.1 million (excluding Crimea and Sevastopol) compared to the same period in 2014 (Russian Federal State Statistics Service 2015a). Similarly, real average wages decreased while the prices of consumer goods increased, especially basic food products like dairy, eggs, fruits and vegetables, and fish (Russian Federal State Statistics Service 2015b). Rising prices were mentioned as the biggest concern by $82 \%$ of Russians in February 2015 and by 69\% in February 2017, heading the list of the most pressing issues in Russian society, followed by poverty, increasing unemployment, and economic crisis (Levada Center 2017a).

Despite this downturn there is little evidence of any serious unravelling of support for the regime. Studies by Rose, Mishler, and Munro (2011, 142-155), McAllister and White (2011) and Greene (2012) have shown that despite the economic crisis in 2008-2009, there was no noticeable drop in support for the regime. Although Putin's approval ratings were affected by the economic downturn, there was no large increase in protest activities around 2008 and Putin's approval ratings never fell much below $60 \%$ (Treisman 2011, 590; Chaisty and Whitefield 2012). The fluctuations of trust in Putin over the years (as a president and prime-minister of Russia) are presented in Figure 1.

How can we explain the high support despite worsening economic conditions, which might be expected to undermine the social contract? We suggest that the continued support for the regime can be explained with the third approach - a dynamic account of the social contract, which implies that the contract can be broadened or reshaped by de-emphasising one type of output (delivery of material well-being) and emphasising another (protection of the national values). By adopting a legitimation strategy stressing nationalist ideas, understood as both protection of traditional Russian values and defending Russia from enemies, especially in the context of the annexation of Crimea, the regime has reduced the salience of economic issues.

According to data from various Russian public opinion centres, after 2010, satisfaction with the direction in which the country is developing is connected with assessments of 
Table 2. Main economic indicators (unless stated otherwise, the data comes from the Russian Federal State Statistics Service*).

\begin{tabular}{|c|c|c|c|c|c|c|c|c|c|c|c|c|c|c|c|c|}
\hline & 2000 & 2001 & 2002 & 2003 & 2004 & 2005 & 2006 & 2007 & 2008 & 2009 & 2010 & 2011 & 2012 & 2013 & 2014 & 2015 \\
\hline Real-money income (\% of the previous year) & 113 & 110 & 111 & 115 & 113 & 112 & 114 & 113 & 104 & 102 & 105 & 101 & 106 & 105 & 100 & 95 \\
\hline Consumer prices (\% of the previous year) & 120 & 119 & 115 & 112 & 112 & 111 & 109 & 112 & 113 & 109 & 109 & 106 & 107 & 107 & 111 & 113 \\
\hline $\begin{array}{l}\text { Minimal food basket cost in Dec (\% in of December } \\
\text { of the previous year) }{ }^{* *}\end{array}$ & 113 & 119 & 113 & 108 & 113 & 111 & 109 & 122 & 118 & 101 & 123 & 94 & 108 & 110 & 115 & 108 \\
\hline Real average monthly wage (\% of the previous year) & 121 & 120 & 116 & 111 & 111 & 113 & 113 & 117 & 112 & 97 & 105 & 103 & 108 & 105 & 101 & 91 \\
\hline People living under the poverty line ( $\%$ of population) & 29 & 27.5 & 24.6 & 20.3 & 17.6 & 17.8 & 15.2 & 13.3 & 13.5 & 13 & 12.5 & 12.7 & 10.7 & 10.8 & 11.2 & 14.1 (Jan-Sept) \\
\hline Real awarded pensions (\% of the previous year) & 128 & 121 & 116 & 105 & 106 & 110 & 105 & 105 & 118 & 111 & 135 & 101 & 105 & 103 & 101 & 96 \\
\hline GINI coefficient ${ }^{* * *}$ & 37.1 & 39.6 & 37.3 & 40.8 & 40.9 & 41.4 & 41.5 & 42.3 & 41.4 & 39.7 & 40.9 & 41.0 & 41.6 & - & - & - \\
\hline
\end{tabular}

* Source: Russian Federal State Statistics Service available at http://www.gks.ru.

**Note from the Russian Federal State Statistics Service: Cost of conventional (minimum) foodstuff basket reflects inter-regional level disparity of consumer prices of the relevant food stuffs.

Unified conventional volumes of consumption of food stuffs, determined across the Russian Federation, and average consumer prices of them in constituent entities of the Russian Federation are used for calculation of the cost.

***World Bank estimates available at: wdi.worldbank.org. 


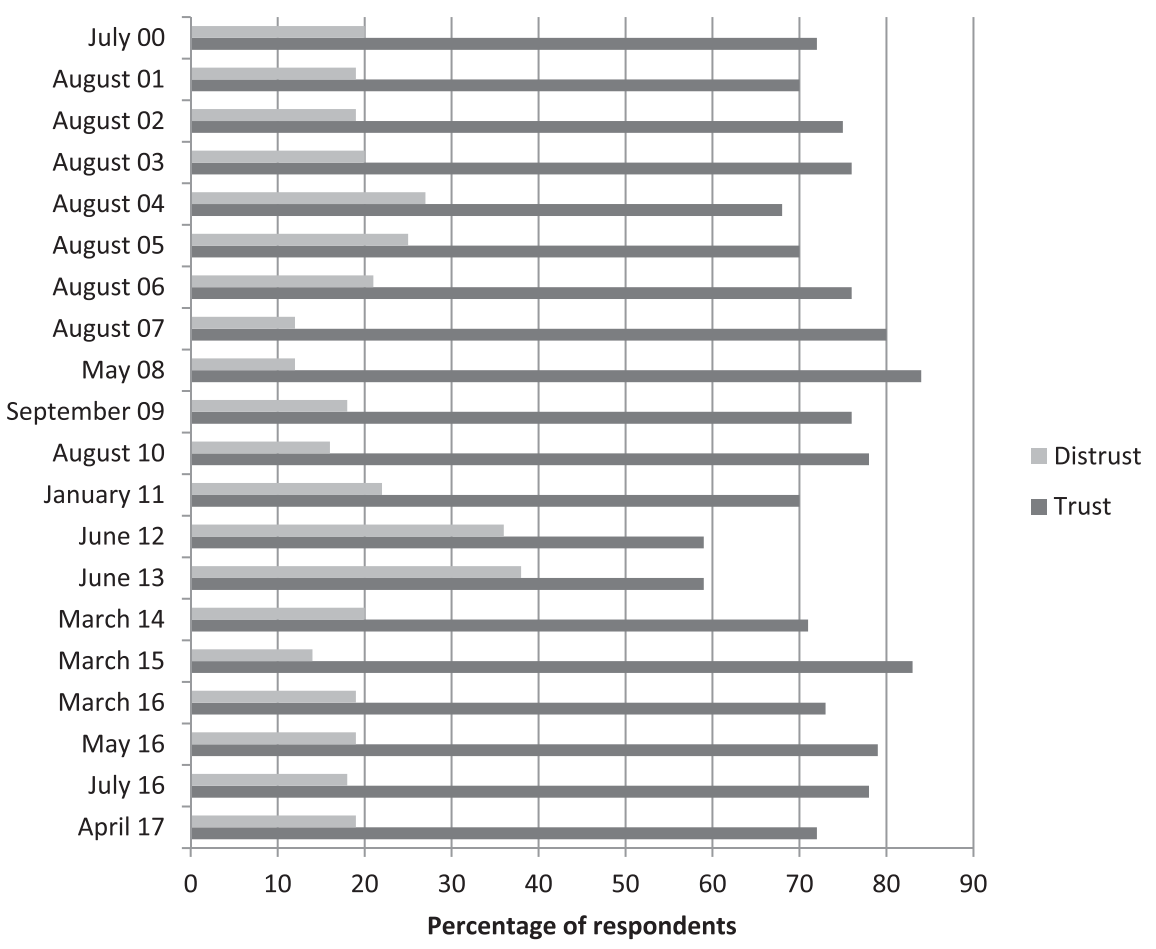

Figure 1. Percentage of respondents expressing trust and distrust in Putin over the years. Source: Levada Center, https://www.levada.ru/2017/04/24/15835/;

Note: Distrust is a sum of "Fully distrust" and "Rather distrust" responses; Trust is a sum of "Fully trust" and "Rather distrust". "Don't know" answers were not included in the graph.

leadership and largely disconnected from economic well-being (Greene 2012, 136-137). For example, in 2010 respondents viewed increasing salaries and benefits as the biggest achievement of Putin's rule (43\%), while in March 2014, most people (51\%) stated that the biggest success of Putin's rule was retrieving the great power status of Russia in the world. At the same time, Putin was evaluated as least successful at securing a just distribution of incomes and returning resources to ordinary people (35\% and $31 \%$ respectively in 2014). One fourth of the respondents thought that Putin had not succeeded in overcoming the economic crisis, strengthening law and order, and raising salaries. He was also considered as completely or partially responsible for Russia's problems by $82 \%$ of respondents (Levada Center 2014b). Despite this criticism, Putin's approval rating hardly dropped below $60 \%$, and his reputation as a charismatic leader is skilfully sustained by the media (White and McAllister 2008).

So far, satisfaction with the regime has remained high (Levada Center 2015a). Similarly, even the protests of 2011 and 2012 were largely disconnected from economic issues as they were a reaction to fraudulent elections to the State Duma in 2011 and Putin's return to the presidency (Robertson 2013). Despite the expectation that the 2011/2012 wave of protest signalled an increase in civic engagement in Russia, on average there was no significant increase in the number of people who participated in public demonstrations (European Social Survey 2015; waves 2006 and 2012). 
During this period, there have been systematic attempts to stress nationalism as a legitimation strategy. In terms of policy, this includes patriotic mobilisation surrounding megaevents like the Sochi Olympics (Persson and Petersson 2014). Most importantly, such mobilisation has also related to the annexation of Crimea, which has featured prominently both in political and also social media discourses (Suslov 2014) - often captured by the exhortation "Krym nash" (Crimea is ours). More generally, in an influential speech to the Federation Council shortly after his election in 2012, President Putin stressed the importance of dukhovnye skrepy (spiritual staples/bonds) (Putin 2012). This is a good example of attempts to conjure up a moralisation of politics and more intense pride in being Russian and associated duties (Sharafutdinova 2017). Thanks in part to positive media coverage of the annexation of Crimea, Putin's approval ratings reached $86 \%$ at the end of June 2014, approaching the peak of $88 \%$ achieved during the 2008 Georgian War (Asmolov, Levinson, and Prokhorova 2014). This pronounced patriotic mobilisation and the widespread conviction that Russia is surrounded by enemies, with the US as the most important one (Levada Center 2015d) has been associated with a marked improvement in the perception of the direction in which Russia is heading, which was boosted by 19 percentage points in June 2014 compared to the level in January 2014 (Levada Center 2017c). This legitimation strategy and its resonance with the population at large seem consistent with key features of the political culture approach, notably the strength of nationalism as well as a sense of vulnerability in the face of international pressures, like economic sanctions (Pipes 2004; Tsygankov 2016).

These changes in legitimation strategies have affected the bases of support for Putin. While it is often said that Russia lacks a coherent ideology justifying the regime, the typical Putin voter during his first two presidential terms tended to be more economically liberal and less nationalistic than the average voter (Colton and Hale 2009), but at the onset of his third presidency, Putin stressed nationalism and conservatism as the core values that unite Russians (Laruelle 2013). Such appeals can be viewed as attempts to reinforce traditional legitimacy. If nationalism and conservatism are perceived to be overarching goals, then having a strong presidency safeguarding these ideals may be viewed as more important than procedural principles and input legitimacy. Over the last few years, the Russian regime has been trying to enhance legitimacy by emphasising the role of tradition, religion, and history and by protecting the common values of Russian society (Torbakov 2014). The governmental plan to introduce a programme on patriotic education and upbringing has met with considerable enthusiasm from the majority of citizens (68\% were in favour of such a programme, while $49 \%$ expressed unqualified support for it; Levada Center 2015c). To the extent that such values are viewed as paramount and the government as an effective guardian of them, this enhances the perceived legitimacy of the government and weakens demands for popular participation and pluralism in politics.

It should also be noted that the Russian regime introduced various restrictions on public organisations and protests in the aftermath of the colour revolutions (Finkel and Brudny 2012). Limiting pluralism in the sphere of political activism was justified by Putin as safeguarding the national interest from foreign encroachment and formalised with various regulations, including the "foreign agent" law. Moreover, loyal and nationalist alternative organisations were created within which youth was mobilised to support the regime and promote patriotism (Horvath 2011; Petrone 2011). These restrictions may 
have contributed to the lack of increase in public engagement such as protests, membership in political parties, or contacting politicians between 2006 and 2012. Another factor explaining the lack of serious challenges to the regime is the fact that a vast majority (around 80\%) do not believe that they can influence politics in any way (Levada Center 2015b; "New Russia Barometer 2009" 2015). However, public opinion surveys show that Russians are not particularly preoccupied with the lack of freedoms in their country as $59 \%$ of respondents in 2012 thought that people in Russia have enough freedom and $18 \%$ believed that Russians enjoy too much of it (Levada Center 2012). Even if Russians had the means to do so, they would not like to participate in political or civic activism (Mickiewicz 2014; Gudkov 2015).

The patriotic and tradition-oriented ideas promoted by the elites seem to resonate with most Russians. Russians tend to separate their lack of approval of the government's actions from general support and pride in their country (Levada Center 2014a). This can partially explain the rise in Putin's popularity whenever he took actions that were presented as defending the abstract national interest of Russia. The wish to recover Russia's lost glory as a great power on the international stage unites Russians in their support for the interventions in Ukraine in 2014 and Georgia in 2008 (Gudkov 2014). Moreover, the consolidation of Russia's international position had become an increasingly important determinant of Putin's approval by 2014 (Hutcheson and Petersson 2016, 1120). In addition, Russians feel great pride in Russia because of its history, armed forces and culture, and much less because of its economic success (Levada Center 2017b). This suggests that political culture has provided a repertoire of symbols and ideas that has served as an effective legitimation strategy for the Putin regime.

In conclusion, while there is some evidence to suggest that regime approval fell after the economic crisis, support quickly rebounded and even increased. The volatility of approval suggests that support is not unconditional. We argue that support has been maintained by renegotiating the social contract and by increasing the salience of nationalism as a key performance indicator for assessing output legitimacy in Russia.

\section{Conclusions: stability, social contract, and legitimation strategies}

This article has discussed political culture and social contract theory and shown that these theories cannot fully account for Russian regime stability. Many traditional political culture explanations overstate the stability of support for the Putin regime. On the other hand, while economic performance generally correlates with support for the regime, the lack of substantial social upheaval during the economic crisis suggests that there are other important bases for the stability of the regime. We suggest that this outcome can be explained through the lens of a dynamic social contract - where previously assessments of the economic situation mattered most, this contract was transformed by increasing the salience of nationalism. This implies that the authorities can reshape the terms of the contract and broaden it, by making alternative "outputs" more salient in people's assessment of the regime. This involves making more extensive use of legitimation strategies that draw on nationalism and ideas that resonate with traditional political culture. This suggests that the social contract between the political authorities and Russian citizens incorporates other dimensions and that it could no longer be sustained purely on the grounds of economic performance. This is also underpinned by Putin's leadership, which capitalises on 
nationalist sentiments of Russian citizens. The convincing narrative of Putin's rule, initially in terms of economic modernisation and strengthening of the state (Sakwa 2008) and more recently as a guardian of the national interest, so far compensates for negative evaluations of virtually all state institutions and for actual economic problems. There are three broader implications of this analysis.

First, this article relates to the growing literature investigating how political authorities use various legitimation strategies to convince citizens that they are rightly in position of power (e.g. Holbig and Gilley 2010; Mazepus et al. 2016; Von Soest and Grauvogel 2016). We have shown how political culture and social contract theory are bound up with different notions of legitimacy and how these theories could be integrated within one framework. Although these theories have generally developed independently of one another, this article suggests that legitimacy, social contract theory and political culture can be fruitfully combined.

Second, this suggests the potential for bridging rationalist and political culture-based accounts of comparative politics. Greater attention to cultural variables could address an important shortcoming of rationalist approaches, namely the lack of attention to processes of preference formation (Hall 2005). Legitimation strategies are not always successful. To the extent that elite strategies have contributed to a reformulation of the social contract in Russia and laid the foundation for stable support for the regime, our argument implies that the resonance of the adopted legitimation strategies with political culture may be an important reason for their success. This would imply that there is some potential for reshaping social contracts, but that such contracts are not infinitely malleable. Successful legitimation strategies that reshape perceived legitimacy and contribute to a stable social contract are likely to be those that are well aligned with prevailing cultural scripts and social preferences. Other comparative studies analysing the use of different legitimation strategies could shed light on the degree to which the success of such strategies varies across cultural contexts. Moreover, they could investigate to what extent nationalism (authorities' emphasis on security of their people and safeguarding particular values of their nation from destructive international factors) is a common element of the existing social contracts in non-democracies and how it contributes to their stability. ${ }^{4}$

Finally, while our analysis suggests that social contracts underpinning regime stability can be adjusted to reflect changing circumstances, the long-term prospects of the Russian social contract remain uncertain. It is easy to overstate the degree of authoritarian stability and not clear whether the support for the regime can be sustained if the economic problems that Russia has been experiencing due in part to the lower oil prices and countersanctions imposed on the West seriously affect the well-being of citizens. The lack of upheaval could suggest that the consequences of the economic crisis were until now not sufficiently severe to bring about greater resistance. If the economic situation were to deteriorate further, then it is not clear whether alternative legitimation strategies would work. A comparison with the Middle East may also be instructive here. Many scholars have used the idea of a social contract to explain state-society relations in the Middle East (e.g. Losman 2010) and suggested that especially natural resource abundant countries offer a favourable bargain to their populations, by which they distribute resource rents in exchange for regime support. As the Arab Spring illustrates, this does not necessarily guarantee the stability of authoritarianism. On the other hand, some regimes in the most resource-abundant countries in the Middle East have been quite robust, which might indicate that economic performance related to oil and gas prices could continue to have an 
important effect on Russian regime developments as well. As shown by Gerschewski (2013), the stability of authoritarian and hybrid regimes tends to depend on three pillars - co-optation, repression and legitimacy. In practice, economic performance will have an important impact on output legitimacy and the regime's ability to co-opt strategic groups. It remains to be seen whether appeals to nationalism will provide a sufficiently strong foundation for regime stability and constitute a durable social contract in the longer term if robust economic growth does not resume.

\section{Notes}

1. We refer to the "Putin regime" given the centrality of Putin to the functioning of the political system in Russia. As demonstrated by various data sources, the popularity of Putin and his regime is not highly correlated with support for various formal institutions in the Russian political system (Hutcheson and Petersson 2016, 1115-1116).

2. Many influential thinkers in the history of Western political thought, from Hobbes, Locke and Rousseau to Rawls and various contemporary theorists, have viewed the social contract as an essential part of their theories of politics (Rawls 1971; Rosenfeld 1984; Waldron 1994). While there are interesting parallels between Russian approaches and social contract tradition in Western thought, we do not consider these questions here (but see Shlapentokh 2003).

3. It should be noted that this social contract does not necessarily presuppose democracy in Russian writings, at least not as conventionally defined in the West (Makarkin and Oppenheimer 2011, 1470). Makarkin suggests that Russians tend to view democracy as a system benefiting the people in socio-economic terms (hence, according to Makarkin, they view both Russia and Belarus as more democratic than an economically struggling albeit politically more open Ukraine).

4. There are some affinities between classical Hobbesian accounts of the social contract "as a means of creating a power capable of holding war at bay" (Forsyth 1994, 42) and the logic of such nationalist legitimation strategies.

\section{Acknowledgements}

The authors would like to thank the three anonymous reviewers for their comments and suggestions.

\section{Disclosure statement}

No potential conflict of interest was reported by the authors.

\section{Notes on contributors}

Magnus Feldmann is a Senior Lecturer in Politics in the School of Sociology, Politics and International Studies at the University of Bristol, UK.

Honorata Mazepus is a post-doctoral researcher at the Institute of Security and Global Affairs at Leiden University on the EU-STRAT project funded by the European Union's Horizon 2020 research and innovation programme.

\section{References}

Ashwin, Sarah. 1998. "Endless Patience: Explaining Soviet and Post-Soviet Social Stability." Communist and Post-Communist Studies 31 (2): 187-198. 
Asmolov, Aleksandr, Alexey Levinson, and Irina Prokhorova. 2014. "Ploskaya Strana [A Flat Country]." Novoye Vremya/The New Times, June 16. http://www.newtimes.ru/articles/detail/83515.

Auzan, Alexader. 2009. "Dynamics of Social Contract." Russia in Global Affairs 2. http://eng. globalaffairs.ru/number/n_13026.

Biryukov, Nikolai, and Victor Sergeyev. 1993. "Parliamentarianism and Sobornost': Two Models of Representative Institutions in Russian Political Culture." Discourse \& Society 4 (1): 57-74.

Bogayevskaya, O. V., G. V. Kalyagin, I. Y. Kobrinskaya, P. V. Kryuchkova, O. V. Makarenko, and I. E. Shul'ga. 2001. Novyi Obshchestvennyi Dogovor: Povestka Dnya [New Social Contract: Agenda]. Edited by O. V. Makarenko and G. V. Kalyagina. Moscow: Institute of National Project "Social Contract".

Brown, Archie, ed. 1985. Political Culture and Communist Studies. Basingstoke: Macmillan.

Carnaghan, Ellen. 2007. “Do Russians Dislike Democracy?" PS: Political Science and Politics 40 (1): 61-66.

Chaisty, Paul, and Stephen Whitefield. 2012. "The Effects of the Global Financial Crisis on Russian Political Attitudes." Post-Soviet Affairs 28 (2): 187-208.

Chechel', Irina, and Aleksandr Markov. 2015. "Alexey Levinson: Obshchestvennogo Kontrakta v Rossii Ne Sushchestvuyet [Alexei Levinson: The Social Contract in Russia Does Not Exist]." Mikhail Gefter. http://gefter.ru/archive/15289.

Colton, Timothy J., and Henry E. Hale. 2009. "The Putin Vote: Presidential Electorates in a Hybrid Regime." Slavic Review 68 (3): 473-503.

Colton, Timothy J., and Michael McFaul. 2002. "Are Russians Undemocratic?" Post-Soviet Affairs 18 (2): 91-121.

Connor, Walter D. 1988. Socialism's Dilemmas: State and Society in the Soviet Bloc. New York: Columbia University Press.

Cook, Linda J. 1992. “Brezhnev's 'Social Contract' and Gorbachev's Reforms." Soviet Studies 44 (1): 37-56.

Cook, Linda J., and Martin K. Dimitrov. 2017. "The Social Contract Revisited: Evidence From Communist and State Capitalist Economies." Europe-Asia Studies 69 (1): 8-26.

Di Palma, Giuseppe. 1991. "Legitimation From the Top to Civil Society: Politico-Cultural Change in Eastern Europe." World Politics 44 (1): 49-80.

Dreger, Christian, Konstantin A. Kholodilin, Dirk Ulbricht, and Jarko Fidrmuc. 2016. "Between the Hammer and the Anvil: The Impact of Economic Sanctions and Oil Prices on Russia's Ruble." Journal of Comparative Economics 44 (2): 295-308.

Eckstein, Harry. 1988. "A Culturalist Theory of Political Change." The American Political Science Review 82 (3): 789-804.

European Social Survey. 2015. "European Social Survey (ESS)." Accessed August 7. http://www. europeansocialsurvey.org/.

Feklyunina, Valentina, and Stephen White. 2011. "Discourses of 'Krizis': Economic Crisis in Russia and Regime Legitimacy." Journal of Communist Studies and Transition Politics 27 (3-4): 385-406.

Finkel, Evgeny, and Yitzhak M. Brudny. 2012. "Russia and the Colour Revolutions." Democratization 19 (1): 15-36.

Forsyth, Murray. 1994. "Hobbes's Contractarianism: A Comparative Approach." In The Social Contract From Hobbes to Rawls, edited by David Boucher and Paul Kelly, 35-50. London: Routledge.

Frye, Timothy, Scott Gehlbach, Kyle L. Marquardt, and Ora John Reuter. 2016. "Is Putin's Popularity Real?" Post-Soviet Affairs. doi:10.1080/1060586X.2016.1144334.

Gaddy, Clifford G., and Barry W. Ickes. 2010. "Russia After the Global Financial Crisis." Eurasian Geography and Economics 51 (3): 281-311.

Gerschewski, Johannes. 2013. "The Three Pillars of Stability: Legitimation, Repression, and CoOptation in Autocratic Regimes." Democratization 20 (1): 13-38.

Gilley, Bruce. 2006. "The Meaning and Measure of State Legitimacy: Results for 72 Countries." European Journal of Political Research 45 (3): 499-525.

Greene, Samuel A. 2012. "Citizenship and the Social Contract in Post-Soviet Russia." Demokratizatsiya 20 (2): 133-140.

Gudkov, Lev. 2014. "Rossiya, kotoruyu vybirayet bol'shinstvo, -kakaya ona? [Russia Chosen by the Majority- What is it Like?]." Interview by V. Dymarskij and K. Larina. Ekho Moskvy. http://www. levada.ru/21-06-2014/rossiya-kotoruyu-vybiraet-bolshinstvo-kakaya-ona. 
Gudkov, Lev. 2015. "Pochemu v 2017 Godu v Rossii Ne Budet Revolutsii [Why There Will Be No Revolution in Russia in 2017]." Moskovskij Komsomolets. http://www.mk.ru/politics/2015/08/06/ pochemu-v-2017-godu-v-rossii-ne-budet-revolyucii.html.

Gudkov, Lev, B. Dubin, N. Zorkaya, O. Bocharova, Alexey Levinson, and A. Lerner. 2001. Obshestvennyi Dogovor, Sotsiologicheskoe Issledovanie [Social Contact. Sociological Research]. Edited by D. Dragunskij. Moscow: Institute for the National Project "Social Contract".

Hahn, Jeffrey W. 2005. "Yaroslavl' Revisited: Assessing Continuity and Change in Russian Political Culture Since 1990." In Political Culture and Post-Communism, edited by Stephen Whitefield, 148-179. London: Palgrave Macmillan.

Hall, Peter A. 1986. Governing the Economy. Oxford: Oxford University Press.

Hall, Peter A. 2005. "Preference Formation as a Political Process: The Case of Monetary Union in Europe." In Preferences and Situations: Points of Intersection Between Historical and Rational Choice Institutionalism, edited by Ira Katznelson and Barry R. Weingast, 129-160. New York: Russell Sage Foundation.

Hauslohner, Peter. 1987. "Gorbachev's Social Contract." Soviet Economy 3 (1): 54-89.

Hedlund, Stefan. 2005. Russian Path Dependence: A People with a Troubled History. London: Routledge. Holbig, Heike, and Bruce Gilley. 2010. "Reclaiming Legitimacy in China." Politics \& Policy 38 (3): 395422.

Holmes, Stephen. 2001. "What Russia Teaches Us Now: How Weak States Threaten Freedom." American Prospect 33: 30-39.

Holmes, Stephen. 2015. "Imitating Democracy, Feigning Capacity." In Democracy in Russian Mirror, edited by Adam Przeworski, 30-57. New York: Cambridge University Press. https://www. cambridge.org/core/books/democracy-in-a-russian-mirror/imitating-democracy-feigningcapacity/534A8D48DB55F844C91D717A3F1A8B14.

Horvath, Robert. 2011. "Putin's 'Preventive Counter-Revolution': Post-Soviet Authoritarianism and the Spectre of Velvet Revolution." Europe-Asia Studies 63 (1): 1-25.

Hutcheson, Derek S., and Bo Petersson. 2016. "Shortcut to Legitimacy: Popularity in Putin's Russia." Europe-Asia Studies 68 (7): 1107-1126.

Jowitt, Ken. 1983. "Neotraditionalism: The Political Corruption of a Leninist Regime." Soviet Studies 35 (3): $275-297$.

Kryshtanovskaya, Olga, and Stephen White. 2009. "The Sovietization of Russian Politics." Post-Soviet Affairs 25 (4): 283-309. doi:10.2747/1060-586X.24.4.283.

Lankina, Tomila. 2015. "The Dynamics of Regional and National Contentious Politics in Russia: Evidence From a New Dataset." Problems of Post-Communism 62 (1): 26-44.

Laruelle, Marlene. 2013. "Conservatism as the Kremlin's New Toolkit: An Ideology at the Lowest Cost." Putin's Turn to Traditionalism/Nationalism 138: 2-4. Russian Analytical Digest. http://e-collection. library.ethz.ch/eserv/eth:7640/eth-7640-01.pdf?pid=eth:7640\&dsID=eth-7640-01.pdf.

Levada Center. 2012. "Rossiyane o demokratii, pravakh i svobodakh [Russians about Democracy, Rights, and Freedoms]." https://www.levada.ru/2012/08/10/rossiyane-o-demokratii-pravah-isvobodah/.

Levada Center. 2013. "Interesy vlasti i obshchestva v predstavleniyakh rossiyan [Interests of Authorities and Interests of Society in the Perception of Russians]." https://www.levada.ru/2014/ 01/28/interesy-vlasti-i-obshhestva-v-predstavleniyah-rossiyan/.

Levada Center. 2014a. "Vospriyatiye Rossiyanami Svoyej Strany [Perceptions of Their Country by Citizens of Russia]." http://www.levada.ru/2014/11/18/vospriyatie-rossiyanami-svoej-strany/.

Levada Center. 2014b. “Vladimir Putin: Udachi i neudachi, sila [Vladimir Putin: Successes and Failures, Strength]." http://www.levada.ru/2014/09/09/vladimir-putin-udachi-i-neudachi-sila/.

Levada Center. 2014c. "Vladimir Putin: Otsenki Deyatelnosti [Vladimir Putin: Evaluation of Work]." https://www.levada.ru/2014/04/18/vladimir-putin-otsenki-deyatelnosti/.

Levada Center. 2015a. "Odobrenie organov vlasti [Approval of the Authorities]." https://www.levada. ru/indikatory/odobrenie-organov-vlasti/.

Levada Center. 2015b. "Vzaimodeistvie grazhdan i gosudarstva [Cooperation between Citizens and the State]." http://www.levada.ru/2015/04/06/vzaimodejstvie-grazhdan-i-gosudarstva/. 
Levada Center. 2015c. "Patriotism i Gosudarstvo [Patriotism and the State]." http://www.levada.ru/2904-2015/patriotizm-i-gosudarstvo.

Levada Center. 2015d. "Ugroza Dlya Rossii so Storony SShA [Danger to Russia from the USA]." http:// www.levada.ru/12-05-2015/ugroza-dlya-rossii-so-storony-ssha.

Levada Center. 2016. "Predstavleniya o legitimnosti vyborov Elections [Impressions of the Legitimacy of Elections]." https://www.levada.ru/2016/07/01/predstavleniya-o-legitimnosti-vyborov/.

Levada Center. 2017a. "Samye ostrye problemy [Most Pressing Issues]." https://www.levada.ru/2017/ 03/07/samye-ostrye-problemy/.

Levada Center. 2017b. "National Pride." https://www.levada.ru/en/2017/05/29/national-pride/.

Levada Center. 2017c. "Yanvarskie reitingi [January Ratings]." https://www.levada.ru/2017/01/25/ yanvarskie-rejtingi-2/.

Losman, Donald L. 2010. "The Rentier State And National Oil Companies: An Economic And Political Perspective." The Middle East Journal 64 (3): 427-445.

Makarkin, Aleksei, and Peter M. Oppenheimer. 2011. "The Russian Social Contract and Regime Legitimacy." International Affairs 87 (6): 1459-1474.

Mazepus, H., W. Veenendaal, A. McCarthy-Jones, and J. M. Trak Vásquez. 2016. "A Comparative Study of Legitimation Strategies in Hybrid Regimes." Policy Studies 37 (4): 350-369.

McAllister, lan, and Stephen White. 2011. "Public Perceptions of Electoral Fairness in Russia." EuropeAsia Studies 63 (4): 663-683. doi:10.1080/09668136.2011.566429.

Mickiewicz, Ellen. 2014. No Illusions: The Voices of Russia's Future Leaders. Oxford: Oxford University Press.

“New Russia Barometer 2009.” 2015. Accessed August 5. http://www.cspp.strath.ac.uk/catalog1_0. html.

Pakulski, Jan. 1986. "Legitimacy and Mass Compliance: Reflections on Max Weber and Soviet-Type Societies." British Journal of Political Science 16 (1): 35-56.

Persson, Emil, and Bo Petersson. 2014. "Political Mythmaking and the 2014 Winter Olympics in Sochi: Olympism and the Russian Great Power Myth." East European Politics 30 (2): 192-209.

Petrone, Laura. 2011. "Institutionalizing Pluralism in Russia: A New Authoritarianism?" Journal of Communist Studies and Transition Politics 27 (2): 166-194.

Pipes, Richard. 2004. "Flight From Freedom-What Russians Think and Want." Foreign Affairs 83: 9-15.

Putin, Vladimir V. 2012. "Poslanie Prezidenta Federal'nomu Sobraniyu [Presidential Address to the Federation Council]." December 12. http://kremlin.ru/events/president/news/17118.

Pye, Lucian W. 1968. "Political Culture." In International Encyclopedia of the Social Sciences. Vol. 12., edited by David L. Sills, 218-225. New York: Macmillan and Free Press.

Rawls, John. 1971. A Theory of Justice. Cambridge, MA: Harvard University Press.

Rigby, Thomas Henry, and Ferenc Fehér. 1982. Political Legitimation in Communist States. London: Macmillan.

Riker, William H. 1984. "The Heresthetics of Constitution-Making: The Presidency in 1787, with Comments on Determinism and Rational Choice." American Political Science Review 78 (1): 1-16.

Robertson, Graeme B. 2011. The Politics of Protest in Hybrid Regimes: Managing Dissent in PostCommunist Russia. Cambridge: Cambridge University Press.

Robertson, Graeme B. 2013. "Protesting Putinism: The Election Protests of 2011-2012 in Broader Perspective." Problems of Post-Communism 60 (2): 11-23.

Rose, Richard, William Mishler, and Neil Munro. 2011. Popular Support for an Undemocratic Regime: The Changing Views of Russians. Cambridge: Cambridge University Press.

Rosenfeld, Michel. 1984. "Contract and Justice: The Relation Between Classical Contract Law and Social Contract Theory." lowa Law Review 70: 769-900.

Russian Federal State Statistics Service. 2015a. "On the Relation of Income and Subsistance Minimum and the Total Number of the Poor People in the Russian Federation in the 1st Quarter of 2015." Accessed June 16, 2015. http://www.gks.ru/bgd/free/b04_03/lssWWW.exe/Stg/d05/111.htm.

Russian Federal State Statistics Service. 2015b. "Short-Term Economic Indicators of the Russian Federation." http://www.gks.ru/bgd/regl/b16_02/Main.htm.

Sakwa, Richard. 2008. "Putin's Leadership: Character and Consequences." Europe-Asia Studies 60 (6): 879-897. 
Schedler, Andreas. 2002. "The Menu of Manipulation." Journal of Democracy 13 (2): 36-50.

Sharafutdinova, Gulnaz. 2017. "Managing National Ressentiment: Morality Politics in Putin's Russia." In Vocabularies of International Relations After the Crisis in Ukraine, edited by Andrey Makarychev and Alexandra Yatsyk, 130-151. London: Palgrave. https://kclpure.kcl.ac.uk/portal/en/ publications/managing-national-ressentiment(d9e8d404-b69c-4866-8a1b-abe1889832e9)/ export.html.

Shlapentokh, Vladimir E. 2003. "Hobbes and Locke at Odds in Putin's Russia." Europe-Asia Studies 55 (7): 981-1007.

Sil, Rudra, and Cheng Chen. 2004. "State Legitimacy and the (In)Significance of Democracy in PostCommunist Russia." Europe-Asia Studies 56 (3): 347-368.

Suslov, Mikhail. 2014. "'Crimea Is Ours!' Russian Popular Geopolitics in the New Media Age." Eurasian Geography and Economics 55 (6): 588-609.

Swidler, Ann. 1986. "Culture in Action: Symbols and Strategies." American Sociological Review 51: $273-$ 286.

Torbakov, Igor. 2014. "The Russian Orthodox Church and Contestations Over History in Contemporary Russia." Demokratizatsiya: The Journal of Post-Soviet Democratization 22 (1): 145170.

Treisman, Daniel. 2011. "Presidential Popularity in a Hybrid Regime: Russia Under Yeltsin and Putin." American Journal of Political Science 55 (3): 590-609.

Tsygankov, A. 2016. "Crafting the State-Civilization Vladimir Putin's Turn to Distinct Values." Problems of Post-Communism 63 (3): 146-158.

Tucker, Robert C. 1992. "Sovietology and Russian History." Post-Soviet Affairs 8 (3): 175-196.

Verba, Sidney. 1965. "Comparative Political Culture." In Political Culture and Political Development, edited by Lucian W. Pye and Sidney Verba, 512-560. Princeton, NJ: Princeton University Press.

Volkov, Denis. 2014. "What Is the Link between Economics and Putin's Popularity?" Russia Beyond the Headlines. http://rbth.co.uk/opinion/2014/06/09/what_is_the_link_between_economics_and_ putins_popularity_37321.html.

Volkov, Denis. 2016. "Astenicheskiy syndrom [Asthenic Syndrome]." Vedomosti, October 4, 2016. http://www.vedomosti.ru/newspaper/articles/2016/10/04/659464-sindrom.

Von Soest, Christian, and Julia Grauvogel. 2016. "Comparing Legitimation Strategies in Post-Soviet Countries." In Politics and Legitimacy in Post-Soviet Eurasia, edited by Martin Brusis, Joachim Ahrens, and Martin Schulze Wessel, 18-46. London: Palgrave Macmillan.

Waldron, Jeremy. 1994. "John Locke: Social Contract Versus Political Anthropology." In The Social Contract From Hobbes to Rawls, edited by David Boucher and Paul Kelly, 51-72. London: Routledge.

Wegren, Stephen K. 2003. "The Rise, Fall, and Transformation of the Rural Social Contract in Russia." Communist and Post-Communist Studies 36 (1): 1-27.

White, Stephen. 1986. "Economic Performance and Communist Legitimacy." World Politics 38 (3): 462-482.

White, Stephen. 2011. "Elections Russian-Style." Europe-Asia Studies 63 (4): 531-556.

White, Stephen, and lan McAllister. 2008. "The Putin Phenomenon." Journal of Communist Studies and Transition Politics 24 (4): 604-628.

Whitefield, Stephen, ed. 2005. Political Culture and Post-Communism. London: Palgrave Macmillan.

Whitefield, Stephen, and Geoffrey Evans. 1999. "Political Culture Versus Rational Choice: Explaining Responses to Transition in the Czech Republic and Slovakia." British Journal of Political Science 29 (1): 29-154.

Wilson, Richard W. 2000. "Review: The Many Voices of Political Culture: Assessing Different Approaches." World Politics 52 (2): 246-273. 